\title{
Development and chemical and sensory characterization of pumpkin seed flour-based cereal bars
}

Jovane Santana SILVA ${ }^{1}$, Tamara Rezende MARQUES ${ }^{1 *}$, Anderson Assaid SIMÃO ${ }^{1}$, Angelita Duarte CORRÊA ${ }^{1}$, Ana Carla Marques PINHEIRO ${ }^{2}$, Renato Leal SILVA ${ }^{2}$

\begin{abstract}
Pumpkin (Cucurbita maxima), popularly known as squash, is a widely grown vegetable in Brazil. In this study, pumpkin seed flours (PSF) with different granulometries were used: PSF 1 (medium granulometry) and PSF 2 (coarse granulometry) in the preparation of cereal bars $(\mathrm{CB})$ with different combinations with brown oats. Five formulations were prepared: $\mathrm{CB}-1$ (control - 25\% brown oats and 0\% PSF); CB-2 (12.5\% PSF 1 and 12.5\% brown oats); CB-3 (25\% PSF 1 and 0\% brown oats); CB-4 (12.5\% PSF 2 and 12.5\% brown oats); and CB-5 (25\% PSF 2 and 0\% brown oats). The acceptance test results were analyzed in a conventional preference mapping which indicated that the bars CB-2 and CB-5 received mostly the maximum hedonistic score. With the objective of developing a cereal bar replacing oats with PSF, the bars CB- 2 and CB-5 were compared to the conventional bar CB-1. The cereal bars CB-2 and CB-5 showed an increase in crude protein (87.5\% and 62.5\%) and in dietary fiber (77\% and 44\%), respectively. These results allowed the classification of CB-2 and CB-5 as fiber sources; they can, therefore, be classified as light products according to the Brazilian legislation.
\end{abstract}

Keywords: Cucurbita maxima; sensory analysis; dietary fiber.

\section{Introduction}

The development of new products and the use of wastes have been more intensively explored in different segments of the Brazilian and global agricultural sector due to the wide variety of available raw material.

During the last decades, the demand for new nutritionally sound and economically viable food has increased considerably. Consequently, much attention has been given to the use of vegetable by-products that are not commonly used by the food industry and the population. The use of these by-products adds value to the production, besides contributing to the formulation of new food products and minimizing losses (Naves et al., 2010).

Accordingly, pumpkin (Cucurbita maxima), popularly known as squash, is a widely grown vegetable in Brazil, especially in the Southeastern region, which had a production of 6,446.40 tons in the state of São Paulo in 2010 (Instituto de Economia Agrícola, 2011). Currently, an increase in processing by industries that commercialize, cut, and package pumpkin has been observed, generating large amounts of waste such as stalks, shells, and mostly seeds.

Studies show that pumpkin seeds have a high content of dietary fiber (DF), in addition to being a protein source and presenting a high percentage of polyunsaturated oils (Naves et al., 2010; Del-Vechio et al., 2005); therefore, they can be used in the preparation of new food products. Beneficial effects such as the reduction in cholesterolemia and blood glucose levels in guinea pigs fed diets containing pumpkin seed flour have been observed (Cerqueira et al., 2008).

An alternative use of pumpkin seed flour is in the preparation of cereal bars since they are small, easy to be consumed requiring little or no preparation by the consumer, and is a source of vitamins, minerals, fibers, proteins, and complex carbohydrates (Izzo \& Niness, 2001). Naves et al. (2010), analyzing pumpkin seed flour, found, in $\mathrm{g} 100 \mathrm{~g}^{-1} \mathrm{dry}$ matter (DM), ether extract (36.41), ash (3.48), crude protein (29.54), and total dietary fiber (22.40), which were higher than those found in oat flour: ether extract (7.00), ash (1.30), crude protein (14.90), and total dietary fiber (10.26) (Universidade de São Paulo, 2008).

Thus, the use of pumpkin seed flour in the formulation of cereal bars can enable product diversification and contribute to aggregate technological and nutritional quality and to reduce environmental impact.

Therefore, the objectives of this study was to use pumpkin seed flour to replace oats in the preparation of CBs (cereal bars), making them more nutritious with diverse functional properties, and to verify its acceptability.

\section{Materials and methods}

\subsection{Materials}

45 intact ripe pumpkins (Cucurbita maxima L.) were purchased from the Municipal Market of Lavras-MG, Brazil.

For the preparation of the CBs (cereal bars), the following ingredients were used: Brown oats (Nattuday); Rice flakes (Harald); Raisins (Rex); Cane syrup (Superbom); Brown sugar (Natturale); Glucose syrup (Yoki), and Salt ( $\mathrm{NaCl})$ (Cisne). 


\subsection{Sample preparation}

The pumpkins were washed and sanitized by soaking in a sodium hypochlorite solution $\left(200 \mathrm{mg} \mathrm{kg}^{-1}\right.$ ) for ten minutes. After drying at room temperature, they were cut into four slices, and the seeds were manually removed and weighed. They were then divided into twelve wire-mesh baskets and placed in a circulating air oven at an average temperature of $40^{\circ} \mathrm{C}$ for 24 hours.

Half of the dry seeds (approximately 1,100 g) was processed using a TECNAL mill (TE-631), in three 20-second stages each, at a speed of 27,000 rpm to obtain a flour with medium granulometry. The pumpkin seed flour (PSF 1) obtained was placed in a tightly closed plastic bottle, protected from light, and stored under refrigeration at $4^{\circ} \mathrm{C}$ and $8^{\circ} \mathrm{C}$. The other half was processed in the same mill, but in one 4-second at a speed of 27,000 rpm to obtain a flour with coarse granulometry. The pumpkin seed flour (PSF 2) obtained was stored under the same conditions used for PSF 1.

\subsection{Granulometry of flours}

In order to determine the granulometry of the pumpkin seed flours, a base and a stack of six sieves with openings ranging between $10 ; 20 ; 40 ; 80 ; 100$, and 140 mesh were used.

\subsection{Elaboration of cereal bars}

The cereal bars (CBs) were formulated containing a dry phase $(53 \%)$ and a binder phase $(47 \%)$, according to Sampaio et al. (2010). The proportion in which the components of the binder phase were combined was determined after pre-testing, and this ratio was used for the preparation of five treatments.

The differences between the treatments were in the composition of the dry phase of the five types of CB, and PSF 1 and 2 were used to replace brown oats, as shown in Table 1.

After the preparation of the CB mass, it was spread on an aluminum foil smeared with a thin layer of hydrogenated vegetable shortening (Primor) and pressed with a spatula in order to obtain the CBs $(2.5 \mathrm{~cm}$ wide and $10 \mathrm{~cm}$ long) with approximately $25 \mathrm{~g}$ each. The CBs were then wrapped in PVC film and aluminum foil, and placed in a tightly closed plastic container at $4^{\circ} \mathrm{C}$ until chemical and sensory analyses. Samples of each treatment were immediately submitted to microbiological analyses.

\subsection{Microbiological analyses}

Counts of bacteria and yeasts were made according to Silva et al. (2010). The microorganisms evaluated were Bacillus cereus, Samonella sp, total and thermotolerant (fecal) coliforms, and the fungus Penicillium sp, according to RDC n ${ }^{\circ} 12$ (Brasil, 2001).

\subsection{Sensory analysis}

The acceptance evaluation of the CBs prepared in this study was approved by the Ethics Committee on research with
Table 1. Formulations of cereal bars (CB) with the addition of pumpkin seed flour (PSF).

\begin{tabular}{|c|c|c|c|c|c|}
\hline \multirow[b]{2}{*}{ Ingredients } & \multicolumn{5}{|c|}{ Treatments } \\
\hline & CB 1 & CB 2 & CB 3 & CB 4 & CB 5 \\
\hline \multicolumn{6}{|l|}{ Dry phase } \\
\hline $\operatorname{PSF} 1^{a}$ & 0 & 12.5 & 25 & 0 & 0 \\
\hline PSF $2^{\mathrm{b}}$ & 0 & 0 & 0 & 12.5 & 25 \\
\hline Brown oats & 25 & 12.5 & 0 & 12.5 & 0 \\
\hline Rice flakes & 25 & 25 & 25 & 25 & 25 \\
\hline Raisins & 3 & 3 & 3 & 3 & 3 \\
\hline \multicolumn{6}{|l|}{ Binder phase } \\
\hline Cane syrup & 20 & 20 & 20 & 20 & 20 \\
\hline Brown sugar & 5.5 & 5.5 & 5.5 & 5.5 & 5.5 \\
\hline Glucose syrup & 21 & 21 & 21 & 21 & 21 \\
\hline Salt $(\mathrm{NaCl})$ & 0.5 & 0.5 & 0.5 & 0.5 & 0.5 \\
\hline Total (\%) & 100 & 100 & 100 & 100 & 100 \\
\hline
\end{tabular}

aPSF 1 - Pumpkin seed flour 1, seed grinding at 27,000 rpm in three 20-second stages. bPSF 2 - Pumpkin seed flour 2, seed grinding at 27,000 rpm in one 4-second stage.

human beings of the Federal University of Lavras (Protocol CAAE - 0022.0.461.000-11).

The sensory evaluation of the CBs was performed by a group of 100 untrained panelists (aged 18-30 years old), who assessed texture, flavor, and overall appearance using a ninepoint hedonic scale, ranging from 1 "dislike extremely" to 9 "like extremely". A five-point hedonic scale was used to asses purchase intention, ranging from 1 "certainly would not buy" to 5 "certainly would buy". The tests were conducted in individual booths, under white light, and the samples (CB-1, CB-2, CB-3, CB-4 and CB-5) were presented to the consumers in balanced order, served in disposable plastic cups, placed on a white bench, and coded with three random digits.

\subsection{Analyses of cereal bars}

In order to choose the best bars, sensory data were statistically analyzed by three-way Internal Preference Mapping (Nunes et al., 2011), which allows the evaluation of sample acceptability according to the panelist's hedonic scores, simultaneously considering the information on the acceptance of several attributes. The three-way preference mapping was obtained by the parallel factor analysis (PARAFAC) (Bro, 1997) from a three-dimensional data set consisting of 5 bars $\times 100$ panelists $\times 5$ attributes.

A recipe of CB-1, CB-2, and $\mathrm{CB}-5, \mathrm{CBs}$ that had a better acceptance, was prepared, as previously described in the methodology, and they were submitted to analyses of chemical and mineral composition, calorific value, $\mathrm{pH}$, soluble solids, acidity index, water activity, color, and texture.

\section{Proximate and mineral composition, caloric value, $p H$, and soluble solids}

The chemical composition of the CBs (moisture, ether extract, crude protein ( $\mathrm{N} \times 6.25)$, ash, dietary fiber, and nitrogenfree extract) was analyzed using the official method described by the Association of Official Analytical Chemists - AOAC (2005). 
In order to quantify minerals $(\mathrm{Ca}, \mathrm{P}, \mathrm{Mg}, \mathrm{S}, \mathrm{Cu}, \mathrm{Mn}, \mathrm{Zn}$, $\mathrm{Fe}, \mathrm{K}$, and $\mathrm{Na}$ ), the CBs were subjected to a nitric-perchloric digestion in digestion blocks with temperature control. $\mathrm{P}$ and $\mathrm{S}$ were determined by colorimetry, $\mathrm{Na}$ and $\mathrm{K}$ by flame photometry, and $\mathrm{Ca}, \mathrm{Mg}, \mathrm{Cu}, \mathrm{Mn}, \mathrm{Zn}$, and $\mathrm{Fe}$ by atomic absorption spectrophotometry (Malavolta et al., 1997). For the determination of the $\mathrm{pH}$ values, the $\mathrm{CB}$ samples were homogenized with distilled water and a digital pHmeter (Schott Handylab) was used (Instituto Adolfo Lutz, 2005).

The content of soluble solids was determined by the readings performed using an Atago hand-held refractometer, $(\mathrm{N}-1 \mathrm{E})$ with ${ }^{\circ} \mathrm{BRIX}$ between 0 and $32 \%$, as described by the AOAC (Association of Official Analytical Chemists, 2005).

The calculations of caloric value for the CBs were performed using ATWATER coefficients ( carbohydrates $=4.0$, lipids $=9.0$, proteins $=4.0$ ).

\section{Acidity index, water activity, color, and texture}

For the determination of the acidity index of the $\mathrm{CB}$ samples, a titration with $0.1 \mathrm{~N} \mathrm{NaOH}$ (Merck) was performed (Instituto Adolfo Lutz, 2005). Water activity in the CBs was determined with a 3 TE AquaLab Water activity meter, series 3B, v 3.0 (Decagon Devices Inc. WA, USA) with a standard water activity of 0.500 , at $25^{\circ} \mathrm{C}$ (Association of Official Analytical Chemists, 2005).

For the color determination of the CBs $\left(L^{*}, a^{*}\right.$ and $\left.b^{*}\right)$, readings were taken using a CM- 5 spectrocolorimeter (Konica Minolta). $\mathrm{L}^{\star}$ (lightness), $\mathrm{a}^{\star}$ (redness), and $\mathrm{b}^{\star}$ (yellowness) readings were based on the CIELab system with the following characteristics: $30.0 \mathrm{~mm}$ measurement area, $10^{\circ}$ angle of view, and illuminant D65 (specular component included).

The CB texture was measured using a SMS TAXT2i texturometer, using a $25 \mathrm{Kg}$ load cell and the software supplied with the equipment (Texture Expert for Windows, version 1.19). To measure shear strength, an HDP/BSK stainless steel blade knife set was used at the rotation speed of $2 \mathrm{~mm} \mathrm{~s}^{-1}$. The maximum shear force, in Newtons $(\mathrm{N})$, was automatically determined by the software program.

Analyses were carried out in the bars in three replicates. The results were evaluated by confidence intervals at $5 \%$ significance (Ferreira, 2009).

\section{Results and discussion}

The pumpkin seed flours showed different granulometrys. Approximately $67 \%$ of PSF 1 showed particles smaller than $1.19 \mathrm{~mm}$, while approximately $80 \%$ of JSF 2 showed particles larger than $1.19 \mathrm{~mm}$. According to Zanotto \& Bellaver (1996), the uniformity index indicates the relative proportion between coarse, medium, and fine particles, which are defined according to diameters larger than $2 \mathrm{~mm}$, between 2 to $0.60 \mathrm{~mm}$, and smaller than $0.60 \mathrm{~mm}$, respectively. Therefore, PSF 1 was classified as medium and PSF 2 was classified as coarse flours.

The microbiological analyses performed in all CBs were in accordance with the RDC $\mathrm{n}^{\circ} 12$ (Brasil, 2001); the bars are suitable for consumption.
In order to choose the most accepted CBs, the sensory acceptability data were analyzed by a three-way internal preference mapping, called PARAFAC, which is a higher order method for data decomposition and can be considered as a generalization of PCA for multidimensional data (Bro, 1997). Preference maps obtained by PARAFAC provide a graphical interpretation of consumers' sensory data, simultaneously considering the several sensory attributes evaluated (Nunes et al., 2011).

In Figure 1, the dispersion of $\mathrm{CB}$ samples prepared without the addition of PSF (CB-1) and with the addition of various concentrations of PSF (CB-2, CB-3, CB-4, and CB-5) is illustrated as a function of consumer acceptance. The spatial dispersion of CB samples suggests the existence of four regions, according to their acceptance; one of the regions is formed by the bars CB-2 and CB-5, and the other bars individually form the other three regions.

The internal preference mapping indicates that the bars CB-2 and CB-5 received the highest scores, a tendency accompanied by the scores for purchase intention. In general, the scores ranged from 6 (like slightly) to 7 (like moderately) for all attributes. Regarding purchase intention, the scores ranged from 3 (maybe would buy) to 4 (would probably buy).

Table 2 shows the results of proximate composition for the cereal bars which were more accepted by the panelists. It can be

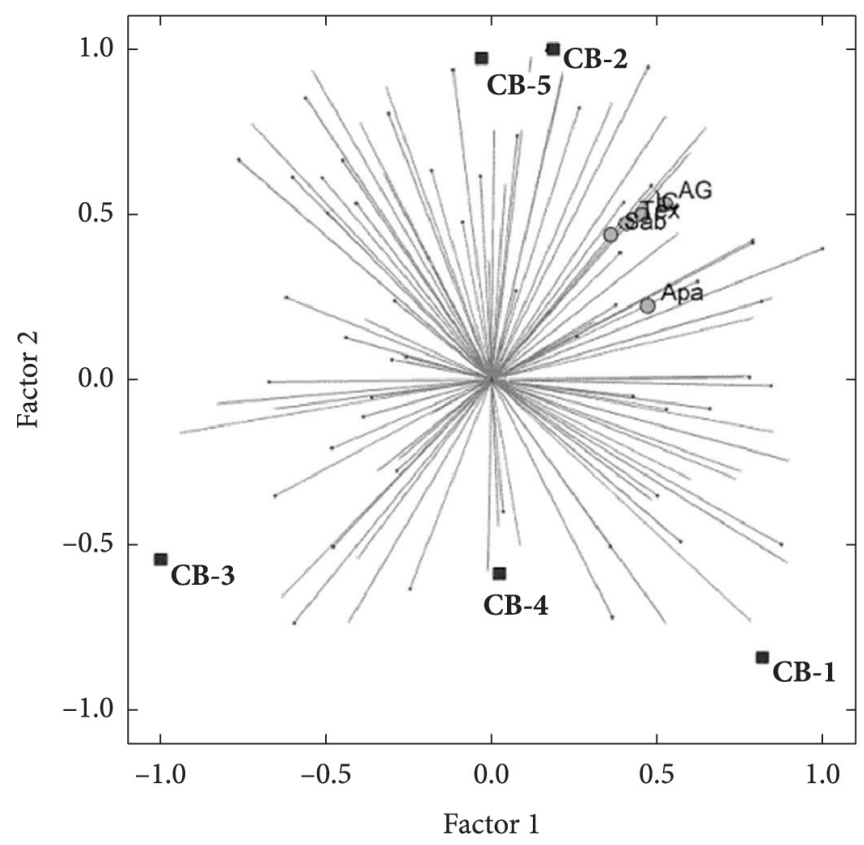

Figure 1. Dispersion of the five cereal bars (CBs) as a function of consumer acceptance of various attributes. $\mathbf{m}=$ samples of the five CBs; $\backslash=$ consumers and $\bigcirc=$ attributes evaluated $(\mathrm{AG}=$ global aspect, Tex=texture, $\mathrm{Sab}=$ flavor, $\mathrm{Apa}=$ overall appearance and $\mathrm{IC}=$ purchase intention). Cereal bars (CB): CB-1: 25\% brown oats and $0 \%$ PSF; CB-2: $12.5 \%$ PSF 1 and $12.5 \%$ brown oats; CB-3: 25\% PSF 1 and $0 \%$ brown oats; CB-4: 12.5\% PSF 2 and 12.5\% brown oats; CB 5: 25\% PSF 2 and $0 \%$ brown oats. 
seen that CB-5 had the lowest moisture content, which differed statistically from CB-1 and CB-2.

Gutkoski et al. (2007) evaluated moisture content in

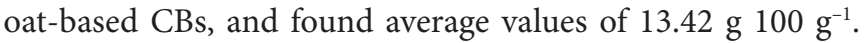
Fonseca et al. (2011) studied CBs prepared with pineapple peels

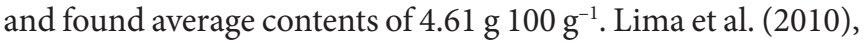
studying cereal bars prepared with baru pulp and almond and Freitas \& Moretti (2006) analyzing cereal bars with soy protein and wheat germ, observed average moisture contents of $9.73 \mathrm{~g}$

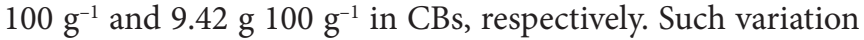
is probably due to the components used in the preparation of the bars. However, these moisture contents are in accordance with RDC Resolution $n^{\circ} 263$, which establishes a $15 \%$ moisture limit for products based on cereals, starches, flours, and brans (Brasil, 2005).

Regarding crude protein, statistical differences between the three bars analyzed were observed. The combination between oats and PSF 1 (CB-2) increased the contents of crude protein in the CB-2, followed by CB-5, in which the total replacement of oats with PSF 2 produced a significant increase in relation to that of CB-1. With regard to the contents of ether extract (Table 2), no significant statistical differences were observed between CB-2 and CB-5. However, it is possible to notice an increasing trend in the content of ether extract due to the addition of PSF, which has higher content of total fat than that of the oats. Similar results were found by Gutkoski et al. (2007), who developed an

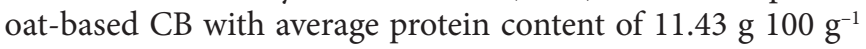

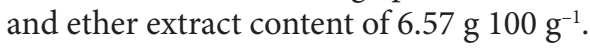

The cereal bar CB-5 had the highest ash content when compared to that of CB-1 and CB-2, which showed no significant differences between each other. As for total and insoluble dietary fiber (DF), there were significant differences between the three CBs (Table 2), and CB-5 showed the highest content. With regard to the soluble DF, CB-5 had the highest content, and there were no significant differences between CB-1 and CB-2.

CB-2 and CB-5 can be classified as rich in dietary fiber because the Brazilian legislation requires a minimum of $6 \mathrm{~g}$ $100 \mathrm{~g}^{-1}$ (for solids) for such classification; thus, they can be claimed as functional food (Brasil, 1998).
With these results, it is evident that PSF increases the contents of DF, which are essential to maintain health and reduce the risk of several diseases, such as cardiovascular diseases and diabetes. Regarding DF, the results of the present study were similar to those reported by Lima et al. (2010), who evaluated

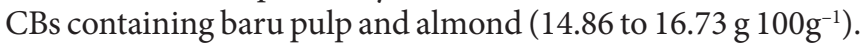

The caloric values of the bars CB-1 and CB-2 showed no significant differences. However, there was a reduction in the caloric content of CB-5 in comparison to the other two bars, a fact associated with the increase in the contents of dietary fiber and crude protein. Therefore, the partial or total replacement of oats with PSF did not increase the caloric value of the CBs, which were within the limits established for CBs considered as light products.

In general, there was an increasing trend in the mineral content (Table 3 ) with the use of PSF for the preparation of CBs. For CB-5, with the total replacement of oats with PSF 2, it was possible to observe the highest contents of these minerals, except for the element sodium, which showed a decrease.

$\mathrm{Ca}$ was not detected in any of the CBs. The levels of $\mathrm{P}, \mathrm{Mn}$, and $\mathrm{Fe}$ had no significant differences between the three CBs analyzed. The contents of $\mathrm{K}, \mathrm{S}, \mathrm{Cu}$, and $\mathrm{Zn}$ in $\mathrm{CB}-1$ and $\mathrm{CB}-2$ showed no significant differences, and they were lower than those of CB-5. The sodium levels found in CB-2 and CB-5 were statistically equal and lower than that found in CB-1.

Paiva et al. (2012), studying CBs elaborated with residues of rice, soy, pineapple, and brown pequi, found higher levels of $\mathrm{P}$, $\mathrm{K}, \mathrm{Mg}, \mathrm{Cu}, \mathrm{Mn}, \mathrm{Zn}$, and $\mathrm{Fe}$ (in $\mathrm{mg} 100 \mathrm{~g}^{-1}$ ), respectively: 175.0 to $275.0,242.5$ to $495.0,97.5$ to $170.0,0.53$ to $0.91,1.40$ to 1.56 , 1.69 to 2.38 , and 3.33 to 5.58 . These differences are probably due to the type of residue used in the preparation of the CBs.

Regarding $\mathrm{Na}$ levels in the CBs analyzed in this study, the contents are $0.3 \%$ lower than the recommended Dietary Reference Intake (DRI), while Fe contents represent 33\% of the DRI in these bars (Organização Pan-Americana da Saúde, 2003).

The recommended $\mathrm{Zn}$ intake is $8 \mathrm{mg} \mathrm{day}^{-1}$ for women and $11 \mathrm{mg} \mathrm{day}^{-1}$ for men. Foods differ in $\mathrm{Zn}$ content, ranging from $0.002 \mathrm{mg} 100 \mathrm{~g}^{-1}$ in egg white and $1 \mathrm{mg} 100 \mathrm{~g}^{-1}$ in chicken to

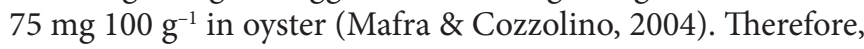

Table 2. Proximate composition ( $\left.100 \mathrm{~g}^{-1}\right)$ and total caloric value (kcal $100 \mathrm{~g}^{-1}$ ) of the cereal bars (CBs).

\begin{tabular}{|c|c|c|c|c|c|c|}
\hline \multirow[b]{2}{*}{ Constituents } & \multicolumn{2}{|c|}{$\mathrm{CB}-1^{*}$} & \multicolumn{2}{|c|}{$\mathrm{CB}-2^{\star *}$} & \multicolumn{2}{|c|}{ CB- $5^{* * *}$} \\
\hline & Mean \pm sd & $\begin{array}{l}\text { Confidence } \\
\text { interval }\end{array}$ & Mean $\pm s d$ & $\begin{array}{c}\text { Confidence } \\
\text { interval }\end{array}$ & Mean \pm sd & $\begin{array}{c}\text { Confidence } \\
\text { interval }\end{array}$ \\
\hline Moisture & $9.92 \pm 0.04$ & 9.8 to 10.0 & $11.45 \pm 0.68$ & 9.4 to 13.5 & $8.60 \pm 0.10$ & 8.4 to 8.8 \\
\hline Crude protein ${ }^{\mathrm{a}}$ & $6.18 \pm 0.37$ & 5.2 to 7.1 & $12.02 \pm 0.39$ & 11.1 to 13.0 & $10.21 \pm 0.15$ & 9.9 to 10.6 \\
\hline Ash & $1.56 \pm 0.05$ & 1.4 to 1.7 & $1.51 \pm 0.12$ & 1.2 to 1.8 & $2.24 \pm 0.34$ & 2.1 to 2.3 \\
\hline Total $\mathrm{DF}^{\mathrm{b}}$ & $3.68 \pm 0.24$ & 3.1 to 4.3 & $6.73 \pm 0.99$ & 5.8 to 8.6 & $19.78 \pm 0.58$ & 18.7 to 20.6 \\
\hline Carbohydrate & $74.63 \pm 0.50$ & 73.4 to 75.9 & $63.34 \pm 0.97$ & 59.6 to 65.0 & $52.59 \pm 0.82$ & 50.9 to 54.5 \\
\hline Total caloric value & $359.59 \pm 2.29$ & 353.5 to 366.4 & $375.71 \pm 7.49$ & 332.6 to 361.2 & $310.39 \pm 4.41$ & 300.9 to 320.8 \\
\hline
\end{tabular}

Overlapping data in the confidence interval indicate that the treatments did not differ ( $\mathrm{p} \leq 0.05)$. ${ }^{\mathrm{a}} \mathrm{Crude}$ protein $\mathrm{N}$ x 6.25 . ${ }^{\mathrm{b}} \mathrm{DF}=\mathrm{Dietary}$ fiber. ${ }^{*} \mathrm{CB}-1: 25 \%$ brown oats and $0 \%$ PSF;

${ }^{* *}$ CB-2: $12.5 \%$ PSF 1 and $12.5 \%$ brown oats; ${ }^{* *}$ CB-5: 25\% PSF 2 and $0 \%$ brown oats. 
based on the Zn contents found in CB-2 and CB-5, they can be considered a good source of this micronutrient.

CBs 1,2 , and 5 showed similar lightness $\left(\mathrm{L}^{*}\right)$ values. As for the $\mathrm{a}^{*}$ values, CB-2 and CB-5 showed a slight tendency to the green color when compared to that of CB- 1 . The $b^{*}$ values characterize the predominance of yellow, and there was no difference between the bars (Table 4).

Regarding texture, the CBs showed significant differences. CB-1 showed an intermediate texture value between those of CB-2 and CB-5. The addition of PSF made CB-2 more compact, possibly due to its smaller granulometry, which increased its strength to cut and hardness. In the case of the total replacement of oats with PSF 2 in the preparation of CB-5, it is possible to observe a decrease in the strength to cut and hardness. The same effect was observed by Silva et al. (2009) with the addition of the industrial waste of passion fruit to produce CBs.

The $\mathrm{pH}$ values of the CBs showed significant differences, indicating an increase in acidity with the addition of PSF. The addition of PSF resulted in an increase in the acidity index of the bars. This difference can be explained by the free fatty acids released from the hydrolysis of triacylglycerols.
The contents of total soluble solids found in CB-2 and CB- 5 showed no significant differences and are smaller than the value determined in CB-1. Regarding water activity, the three CBs showed no significant differences, and the values were lower than 0.6 , which is beneficial for the preservation of the product.

Glaser (2011) conducted a study comparing 30 types of CBs from 10 different brands sold in Brazil. The nutritional information was removed from the labels. With a weight of $25 \mathrm{~g}$ per portion, amounts of energy value, carbohydrates, protein, total fat, dietary fiber, and sodium between $72 \mathrm{kcal}$ and $114 \mathrm{kcal}$, $14 \mathrm{~g}$ and $21 \mathrm{~g}, 0.9 \mathrm{~g}$ and $5.6 \mathrm{~g}, 0.3 \mathrm{~g}$ and $4.7 \mathrm{~g}, 1.0 \mathrm{~g}$ and $7.5 \mathrm{~g}$, $15 \mathrm{mg}$ and $120 \mathrm{mg}$, respectively, were found.

Comparing the contents of the constituents analyzed in the bars CB-1, CB-2, and CB-5 with those reported by Glaser (2011), it is possible to consider that they are within the nutritional values reported for commercial CBs brands.

Table 5 shows the nutritional value of the cereal bars (CB-1, CB-2, and CB-5); it can be seen that the use of pumpkin seed flour caused a decrease in total energy of CB- 2 and CB- 5 when compared to that of CB-1, which had a low caloric value ( $90 \mathrm{kcal}$ per each $25 \mathrm{~g}$ portion).

Table 3. Mineral composition of the cereal bars (CBs).

\begin{tabular}{|c|c|c|c|c|c|c|}
\hline \multirow[b]{2}{*}{ Minerals } & \multicolumn{2}{|c|}{$\mathrm{CB}-1^{*}$} & \multicolumn{2}{|c|}{ CB- $2^{* *}$} & \multicolumn{2}{|c|}{ CB- $5^{* * *}$} \\
\hline & Mean \pm sd & $\begin{array}{c}\text { Confidence } \\
\text { interval }\end{array}$ & Mean \pm sd & $\begin{array}{c}\text { Confidence } \\
\text { interval }\end{array}$ & Mean \pm sd & $\begin{array}{c}\text { Confidence } \\
\text { interval }\end{array}$ \\
\hline Calcium $^{\mathrm{b}}$ & $\mathrm{nd}^{\mathrm{a}}$ & ------- & $\mathrm{nd}^{\mathrm{a}}$ & ------- & $\mathrm{nd}^{\mathrm{a}}$ & ------- \\
\hline Phosphorus $^{\mathrm{b}}$ & $0.20 \pm 0.02$ & 0.15 to 0.26 & $0.23 \pm 0.01$ & 0.21 to 0.25 & $0.28 \pm 0.01$ & 0.26 to 0.30 \\
\hline Potassium $^{\mathrm{b}}$ & $0.16 \pm 0.01$ & 0.13 to 0.19 & $0.12 \pm 0.01$ & 0.09 to 0.15 & $0.37 \pm 0.01$ & 0.34 to 0.40 \\
\hline Magnesium $^{\mathrm{b}}$ & $0.14 \pm 0.01$ & 0.11 to 0.17 & $0.08 \pm 0.01$ & 0.06 to 0.09 & $0.13 \pm 0.01$ & 0.13 to 0.13 \\
\hline Sulphur ${ }^{\mathrm{b}}$ & $0.12 \pm 0.01$ & 0.10 to 0.13 & $0.12 \pm 0.00$ & 0.12 to 0.12 & $0.24 \pm 0.00$ & 0.24 to 0.24 \\
\hline Copper ${ }^{c}$ & $3.83 \pm 0.35$ & 3.00 to 4.70 & $3.17 \pm 0.47$ & 2.00 to 4.30 & $5.10 \pm 0.26$ & 4.40 to 5.80 \\
\hline Manganese $^{c}$ & $29.76 \pm 4.22$ & 19.30 to 40.20 & $27.46 \pm 1.33$ & 24.20 to 30.80 & $24.13 \pm 0.68$ & 22.40 to 25.80 \\
\hline Zinc $^{c}$ & $19.92 \pm 3.27$ & 11.80 to 28.00 & $16.0 \pm 1.59$ & 11.60 to 19.50 & $27.27 \pm 0.81$ & 25.30 to 29.30 \\
\hline $\operatorname{Iron}^{\mathrm{c}}$ & $46.37 \pm 2.94$ & 39.10 to 53.70 & $46.97 \pm 5.42$ & 33.50 to 60.40 & $57.13 \pm 3.73$ & 47.90 to 66.40 \\
\hline Sodium $^{c}$ & $153.23 \pm 0.15$ & 152.90 to 153.60 & $131.26 \pm 0.96$ & 128.90 to 133.60 & $129.70 \pm 0.49$ & 128.50 to 130.90 \\
\hline
\end{tabular}

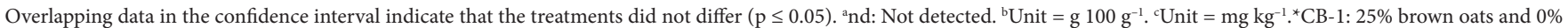
PSF; ${ }^{* *}$ CB-2: $12.5 \%$ PSF 1 and $12.5 \%$ brown oats; ${ }^{* *}$ CB- $5: 25 \%$ PSF 2 and $0 \%$ brown oats.

Table 4. Evaluation of the color parameters $\left(\mathrm{L}^{\star}, \mathrm{a}^{\star}\right.$, and $\left.\mathrm{b}^{\star}\right)$, texture, $\mathrm{pH}$, soluble solids, water activity, and acidity index of the cereal bars $(\mathrm{CBs})$.

\begin{tabular}{|c|c|c|c|c|c|c|}
\hline \multirow[b]{2}{*}{ Parameters } & \multicolumn{2}{|c|}{$\mathrm{CB}-1^{*}$} & \multicolumn{2}{|c|}{ CB-2** } & \multicolumn{2}{|c|}{ CB- $5^{\star * *}$} \\
\hline & Mean \pm sd & $\begin{array}{c}\text { Confidence } \\
\text { interval }\end{array}$ & Mean \pm sd & $\begin{array}{c}\text { Confidence } \\
\text { interval }\end{array}$ & Mean \pm sd & $\begin{array}{c}\text { Confidence } \\
\text { interval }\end{array}$ \\
\hline $\mathrm{L}^{*}$ & $57.28 \pm 0.03$ & ------- & $58.24 \pm 0.82$ & ------ & $57.07 \pm 0.13$ & ------ \\
\hline$a^{*}$ & $6.12 \pm 0.03$ & ------ & $3.76 \pm 0.03$ & ------ & $3.48 \pm 0.34$ & ------ \\
\hline $\mathrm{b}^{*}$ & $20.40 \pm 0.06$ & ------- & $19.41 \pm 0.43$ & ------- & $21.15 \pm 0.16$ & ------- \\
\hline Texture (gF) & $2.62 \pm 155.62$ & 2.36 to 3.01 & $4.99 \pm 293.22$ & 4.24 to 5.69 & $2.02 \pm 82.88$ & 1.81 to 2.22 \\
\hline $\mathrm{pH}$ & $5.43 \pm 0.02$ & 5.37 to 5.48 & $5.75 \pm 0.02$ & 5.71 to 5.78 & $5.60 \pm 0.01$ & 5.57 to 5.63 \\
\hline $\begin{array}{l}\text { Soluble } \\
\left.\text { solids ( }{ }^{\circ} \text { Brix }\right)\end{array}$ & $45.46 \pm 0.27$ & 44.80 to 46.12 & $42.97 \pm 0.25$ & 42.35 to 43.58 & $43.37 \pm 0.01$ & 42.82 to 43.91 \\
\hline $\begin{array}{l}\text { Water } \\
\text { activity }_{\text {aw }}\end{array}$ & $0.53 \pm 0.01$ & 0.53 to 0.54 & $0.53 \pm 0.00$ & 0.53 to 0.53 & $0.53 \pm 0.01$ & 0.53 to 0.54 \\
\hline $\begin{array}{l}\text { Acidity index } \\
\left(\mathrm{mL} \mathrm{NaOH} \mathrm{g}^{-1}\right)\end{array}$ & $2.00 \pm 0.01$ & 73.40 to 75.90 & $2.88 \pm 0.02$ & 59.60 to 65.00 & $3.58 \pm 0.01$ & 50.90 to 54.50 \\
\hline
\end{tabular}

Overlapping data in the confidence interval indicate that the treatments did not differ ( $\leq \leq 0.05) .{ }^{*} \mathrm{CB}-1: 25 \%$ brown oats and $0 \%$ PSF; ${ }^{* *} \mathrm{CB}-2: 12.5 \%$ PSF 1 and $12.5 \%$ brown oats; ${ }^{* * *}$ CB-5: $25 \%$ PSF 2 and $0 \%$ brown oats. 
Table 5. Nutritional information on the cereal bars CB-1, CB-2, and CB-5.

\begin{tabular}{lccc}
\hline & \multicolumn{1}{c}{ Amount per serving (25-g portion - 1 bar) } & CB-5 $^{\text {***}}$ \\
\hline & CB-1 & CB-2 $^{* *}$ & $78 \mathrm{kcal}=326 \mathrm{~kJ}$ \\
Energy value & $90 \mathrm{kcal}=377 \mathrm{~kJ}$ & $88 \mathrm{kcal}=367 \mathrm{~kJ}$ & 13.2 \\
Carbohydrates (g) & 18.7 & 15.8 & 2.6 \\
Proteins (g) & 1.6 & 3.0 & 1.6 \\
Total fat (g) & 1.0 & 1.4 & 4.9 \\
Dietary fiber (g) & 0.9 & 1.7 & 1.4 \\
Iron (mg) & 1.2 & 1.2 & 0.7 \\
Zinc (mg) & 0.5 & 0.4 & 3.2 \\
Sodium (mg) & 3.8 & 3.3 & 3.2 \\
\hline
\end{tabular}

${ }^{\star} \mathrm{CB}-1$ : $25 \%$ brown oats and $0 \%$ PSF; ${ }^{* *} \mathrm{CB}-2: 12.5 \%$ PSF 1 and $12.5 \%$ brown oats; ${ }^{* * *} \mathrm{CB}-5: 25 \%$ PSF 2 and $0 \%$ brown oats.

According to Ordinance n' $27 / 98$ of Secretaria de Vigilância Sanitária do Ministério da Saúde, Health Vigilance Secretariat of the Health Department, which deals with complementary nutritional information, the cereal bars CB-1, CB-2 and CB-5 can be classified as light products (Brasil, 1998) when compared with the cereal bars found in the market (Glaser, 2011).

Fat contents showed an increase in the bars CB-2 and CB-5 when compared to $\mathrm{CB}-1$ due to the high content of lipids present in PSF. However, they were lower than the average contents of $2.5 \mathrm{~g}$, reported for commercial CBs brands (Brito et al., 2004).

Regarding protein content, the cereal bars CB- 2 and CB- 5 showed an increase of $87.5 \%$ and $62.5 \%$, respectively, and the content found was $1.6 \mathrm{~g}$ per each $25 \mathrm{~g}$ portion.

As for the content of dietary fiber, the cereal bars CB-2 and CB-5 showed an increase of $88 \%$ and $444 \%$, respectively, and the content found was $0.9 \mathrm{~g}$ per each $25 \mathrm{~g}$ portion.

These results indicate that due to the nutritional information obtained for the cereal bar CB-2, it can be considered a source of fiber, and CB-5 can be considered a product with a high fiber content.

\section{Conclusion}

The replacement of oats with PSF 1 and PSF 2 (50\% and $100 \%)$ in the preparation of the cereal bars CB-2 and CB-5 led to improvements in sensory attributes (aspect, texture, flavor, overall appearance and purchase intention), and consumer preference.

The use of PSF 1 and PSF 2 in the formulation of the cereal bars CB-2 (with the addition of $12.5 \%$ PSF 1 and $12.5 \%$ brown oats) and CB-5 (with the addition of 25\% PSF and $0 \%$ brown oats) resulted in products with a higher nutritional value, meeting the current demands of the consumer market with a low sodium content and energy value, and these products can be classified as light products with high contents of dietary fiber, and they are therefore an alternative to consumers of healthy and functional food.

Furthermore, the partial replacement of oats with pumpkin seed flour may result in a cheaper product, adding value to these by-products and avoiding their disposal in the environment.

\section{Acknowledgements}

The authors are grateful for the financial support provided by Minas Gerais State Research Foundation, Fundação de Amparo a Pesquisa de Minas Gerais - FAPEMIG, Coordination for the Improvement of Higher Education Personnel, Coordenação de Aperfeiçoamento de Pessoal de Nível Superior - CAPES, and The National Council for Scientific and Technological Development, Conselho Nacional de Desenvolvimento Científico e Tecnológico - CNPq.

\section{References}

Association of Official Analytical Chemists - AOAC. (2005). Official methods of analysis (18th ed.). Washington: AOAC.

Brasil, Agência Nacional de Vigilância Sanitária. (1998). Aprova o Regulamento Técnico referente à Informação Nutricional Complementar (Resolução RDC nº 27 de 1998). Diário Oficial da União.

Brasil, Agência Nacional de Vigilância Sanitária. (2005). Aprova o regulamento técnico para produtos de cereais, amidos, farinhas e farelos (Resolução RDC nº 263 de 2005). Diário Oficial da União.

Brasil, Ministério da Saúde. (2001). Aprova o regulamento técnico sobre padrões microbiológicos para alimentos (Resolução RDC no 12 de 02 de janeiro de 2001). Diário Oficial da União.

Brito, I. P., Campos, J. M., Souza, T. F. L., Wakiyama, C., \& Azeredo, G. A. (2004). Elaboração e avaliação global de barra de cereais caseira. Boletim do Centro de Pesquisa de Processamento de Alimentos, 22(1), 35-50.

Bro, R. (1997). PARAFAC: tutorial and applications. Chemometrics and Intelligent Laboratory Systems, 38(2), 149-171. http://dx.doi. org/10.1016/S0169-7439(97)00032-4

Cerqueira, P. M., Freitas, M. C. J., Pumar, M., \& Santangelo, S. B. (2008). Efeito da farinha de semente de abóbora (Curcubita maxima, L.) sobre o metabolismo glicídico e lipídico em ratos. Revista de Nutrição, 21(2), 129-136. http://dx.doi.org/10.1590/ S1415-52732008000200001

Del-Vechio, G., Corrêa, A. D., Abreu, C. M. P., \& Santos, C. D. (2005). Efeito do tratamento térmico em sementes de abóboras (cucurbita spp.) sobre os níveis de fatores antinutricionais e/ou tóxicos. Ciência e Agrotecnologia, 29(2), 369-376. http://dx.doi.org/10.1590/S141370542005000200014

Ferreira, D. F. (2009). Estatística básica (2. ed.). Lavras: UFLA.

Fonseca, R. S., Del Santo, V. R., Souza, G. B., \& Pereira, C. A. M. (2011). Elaboração de barra de cereais com casca de abacaxi. Archivos Latinoamericanos de Nutrición, 61(2), 216- 223. PMid:22308949. 
Freitas, D. G. C., \& Moretti, R. H. (2006). Caracterização e avaliação sensorial de barra de cereais functional de alto teor protéico e vitamínico. Food Science and Technology, 26(2), 318-324.

Glaser, Y. (2011). Comparação dos valores nutricionais das barrinhas de cereais. MundoTri. Retrieved from http://www.mundotri.com.br

Gutkoski, L. C., Bonamigo, J. M. A., Teixeira, D. M. F., \& Pedó, I. (2007). Desenvolvimento de barras de cereais à base de aveia com alto teor de fibra alimentar. Food Science and Technology, 27(2), 355-363.

Instituto Adolfo Lutz - IAL. 2005. Métodos físico-químicos para análise de alimentos (4. ed.). São Paulo: IAL, 2005.

Instituto de Economia Agrícola - IEA. 2011. Banco de dados. São Paulo: IEA. Retrieved from www.iea.sp.gov.br/out/banco/menu.php

Izzo, M., \& Niness, K. (2001). Formulating nutrition bars with inulin and oligofructose. Cereal Foods World, 46(3), 102-105.

Lima, J. C. R., Freitas, J. B., Czeder, L. P., Fernandes, D. C., \& Naves, M. M. V. (2010). Qualidade microbiológica, aceitabilidade e valor nutricional de barras de cereais formuladas com polpa e amêndoa de baru. Boletim do Centro de Pesquisa de Processamento de Alimentos, 28(2), 331-343.

Mafra, D., \& Cozzolino, S. M. F. (2004). Importância do zinco na nutrição humana. Revista de Nutrição, 17(1), 79-87. http://dx.doi. org/10.1590/S1415-52732004000100009

Malavolta, E., Vitti, G. C., \& Oliveira, A. S. (1997). Avaliação do estado nutricional das plantas: princípios e aplicações. Piracicaba: POTAFOS.

Naves, L. P., Corrêa, A. D., Santos, C. D., Natividade, M. A. E., \& Abreu, C. M. P. (2010). Nutrientes e propriedades funcionais em sementes de abóbora (Cucurbita maxima) submetidas a diferentes processamentos. Ciência e Tecnologia de Alimentos, 30(Supl. 1), 185190. http://dx.doi.org/10.1590/S0101-20612010000500028

Nunes, C. A., Pinheiro, A. C. M., \& Bastos, S. C. (2011). Evaluating consumer acceptance tests by three-way internal preference mapping obtained by parallel factor analysis (PARAFAC). Journal of Sensory Studies, 26(2), 167-174. http://dx.doi.org/10.1111/j.1745459X.2011.00333.X

Organização Pan-Americana da Saúde - OPAS. 2003. Doenças crônicodegenerativas e obesidade: estratégia mundial sobre alimentação saudável, atividade física e saúde. Brasília: OPAS.

Paiva, A. P., Barcelos, A. F. P., Pereira, J. A. R., \& Ciabotti, E. B. F. (2012). Characterization of food bars manufactured with Agroindustrial by-products and waste. Ciência e Agrotecnologia, 36(3), 333-340. http://dx.doi.org/10.1590/S1413-70542012000300009

Sampaio, C. R. P., Ferreira, S. M. R., \& Canniatti-Brazaca, S. G. (2010). Caracterização físico-química e composição de barras de cereais fortificadas com ferro. Alimentos e Nutrição, 21(4), 607-616.

Silva, I. Q., Oliveira, B. C. F., Lopes, A. S., \& Pena, R. S. (2009). Obtenção de barra de cereais adicionadas do resíduo industrial de maracujá. Alimentos e Nutrição, 20(2), 321-329.

Silva, N., Junqueira, V. C. A., \& Silveira, N. F. A. (2010). Manual de métodos de análise microbiológica de alimentos. São Paulo: Livraria Varela.

Universidade de São Paulo - USP. 2008. Tabela Brasileira de Composição de Alimentos: TBCA. São Paulo: USP. Retrieved from http://www. fcf.usp.br/tabela

Zanotto, D. L., \& Bellaver, C. (1996). Método de determinação da granulometria de ingredientes para uso em rações de suínos e aves. Concórdia: Embrapa. Comunicado Técnico. 